\title{
Initial preference of oviposition sites: discrimination between living and dead plant material in Sympecma fusca and Coenagrion caerulescens (Odonata: Lestidae, Coenagrionidae)
}

\author{
ANDREAS MARTENS \\ Zoologisches Institut der Technischen Universität Braunschweig, Fasanenstrasse 3, D-38092 Braunschweig, Germany; \\ e-mail: andreas.martens $(a$ tu-bs.de
}

Key words. Odonata, Zygoptera, Lestidae, Coenagrionidae, Sympecma fusca, Coenagrion caerulescens, reproductive behaviour, oviposition site selection, aggregation behaviour

\begin{abstract}
Sympecma fusca and Coenagrion caerulescens mainly deposit their eggs into floating dead parts of emergent plants. In their initial choice of oviposition site (selection of landing site) $S$. fusca does not distinguish between fresh and dead plant material, whereas $C$. caerulescens significantly prefers dead material. In $S$. fusca, the missing discrimination of the plant condition in the choice of the landing site is explained by its oviposition period in the beginning of the vegetation period when the green plant material is rare. C. caerulescens reproduces in summer and finds dead and living plants side by side. I suggest that in the latter species an early recognition of dead material is advantageous because of the reduction of the expense in searching.
\end{abstract}

\section{INTRODUCTION}

Zygoptera deposit their eggs into plant material. Their choice of oviposition site may be divided into three steps, (1) selection of a landing site (= "initial preference"; Waage, 1987), (2) choice of the insertion site, and (3) the deposition of eggs. In the selection of a landing site distinct plant structures, water reflections, size and locality of the substrate as well as conspecifics are important stimuli (Martens, 1992, 1993, 1994; Waage, 1987). Three aspects can be suggested as important: (1) the offspring should be placed at the best site for further development. (2) The ovipositing female or pair should minimise the predation risk. (3) The duration of oviposition should last as short as possible to have more time for foraging, for further mate searching and to achieve shorter interclutch intervals. The last two aspects are especially important because adult females produce eggs continuously during their life span and the reproductive success of both sexes depends on longevity (Banks \& Thompson, 1985, 1987).

Dragonflies loose considerable time in testing possible oviposition sites without success (Martens, 1992) which prolongs their daily reproductive period. A zygopteran species should evolve an early recognition of a suitable oviposition site. In this paper I will focus on the recognition of plant condition in oviposition site selection. Choice experiments were made with two different species, both of which deposit eggs in tandem and mainly use dead plant material. However, one species (Sympecma fusca) probably rarely encounters living macrophytes in the water while the other (Coenagrion caerulescens) does. Thus, discrimination is more likely in the second species. This was tested by choice experiments with living and dead plant material in the field.

\section{MATERIAL AND METHODS}

Sympecma fusca (Vander Linden, 1820) is a medium-sized zygopteran, widely distributed in Europe, North Africa and western Asia (Jödicke, 1997). Both sexes are inconspicuously brown. The reproductive period lasts from mid March to early May. Oviposition was studied between 1989 and 1995 in the "Birkenmoor" (52 $\left.27^{\prime} 15^{\prime \prime} \mathrm{N}, 10^{\circ} 27^{\prime} 10^{\prime \prime} \mathrm{E}\right)$ near Gifhorn, northern
Germany. The bog pond had a maximum size of $200 \times 120 \mathrm{~m}$ and showed significant markings of overgrowth and eutrophication. The vegetation was dominated by Typha latifolia and Carex spp. Beside this Eriophorum sp., Scirpus silvatica, Juncus effusus and Eleocharis palustris grew in smaller areas. In April and early May, the water was rich in dead, floating plant material, mostly brown $T$. latifolia leaves. Only Carex and Eriophorum were fully grown, while Typha emerged above the water and Potamogeton natans, as well as Nymphaea alba, appeared with their first floating leaves.

The choice experiment described here was conducted on 1 and 2 April 1990. Within an area of $3 \times 4 \mathrm{~m}$ I removed the plant material suitable for oviposition, and exposed 6 green and 6 brown $T$. latifolia leaves, each $30 \mathrm{~cm}$ in length, alternately in two rows. The green pieces were parts from just emerged plants, the brown ones from dead plants from the previous year. When a tandem landed on the substrate, the position, duration of stay and behaviour were recorded.

Coenagrion caerulescens (Fonscolombe, 1838) is a mediumsized zygopteran, the body is blue with sexually dimorphic black markings. It is distributed in south-western Europe and North Africa and inhabits running waters (Schmidt, 1959). The flight period lasts from May to August (Wendler \& Nüss, 1991).

The species was studied from 20 to 30 June 1993 at the Canal de Vergières (southern France, $5^{\circ} 18^{\prime} 20^{\prime \prime} \mathrm{N}, 10^{\circ} 4^{\prime} 20^{\prime \prime} \mathrm{E}$ ). This canal and its dragonfly fauna were described in detail by Rehfeldt et al. (1991) and Schridde \& Suhling (1994). Discrimination experiments were performed on a stretch with a width of $2.2-4.0 \mathrm{~m}$ and a maximum depth of $0.5 \mathrm{~m}$. The vegetation consisted of Mentha aquatica, Typha angustifolia, Scirpus holoschoemus, Potamogeton coloratus, Juncus sp., Chara spp., and Rubus ulmifolius.

During previous observations it was striking that pairs concentrated on distinct localities and females mainly oviposited into dead brown plant material. For this reason I undertook an experiment which tested simultaneously aggregation behaviour and the preference for a distinct plant material. A pair of wooden sticks forming a frame were placed in a floating Chara mat at a distance of $0.7-0.9 \mathrm{~m}$ from the bank. Between these sticks I pinned different pieces of Scirpus holoschoenus leaves, 
$30 \mathrm{~cm}$ long and $0.4 \mathrm{~cm}$ wide. Two sites consisted of one green and one brown piece at a distance of $30 \mathrm{~cm}$.

Dead conspecifics were used as models in the experiment. Specimens were caught and prepared just before starting. The models were fixed to one pair of leaves with insect pins. Females were placed in an egg-laying position, while males were fixed at the level of the prothorax of the female in a vertical position. In a second treatment the tandem was replaced by a male in vertical position.

When a tandem landed at one of the prepared substrates the direction of approach, the landing site, the duration of stay and behaviour of the pair were recorded. If a female touched the plant material with her abdomen this behaviour was considered as an attempt to oviposit. After the tandem had flown off, the model was pinned to the alternative site. $C$. caerulescens and $C$. mercuriale, which are very similar in size, colour and body markings, were present during the same period on the canal. Using a field monocular I could distinguish between this species and $C$. caerulescens by the abdominal markings on segment 6 of the male (Wendler \& Nüss, 1991).

\section{RESULTS}

\section{Sympecma fusca}

In the Birkenmoor, $S$. fusca females mainly oviposited into floating fragments of Typha latifolia grown the year before but they also used dead parts of Eleocharis palustris and Carex spp. Eggs were always placed in horizontal material. They were inserted in the upper side or laterally in wet plant parts at or just below the water surface. Each egg was inserted into its own incision in irregular patterns but parallel to one another in plant tissue. Females also palpated fresh floating Carex leaves, but there was no evidence of any oviposition. In one case, eggs were deposited into the fresh floating leaves of Nymphaea alba, where, contrary to all other plants recorded here, eggs were visible just after deposition.

During the experiments the pairs showed no clear preference for dead brown material with 12 landings on green and 17 on brown plant pieces $\left(\chi^{2}=0.86\right.$; d.f. $=1$; N.S. $)$. In landing, the tandem-male settled and took a horizontal position. The female then curved her abdomen and touched the plant material with her ovipositor, brown pieces for a mean of $24.3 \mathrm{~s}( \pm 17.0 \mathrm{~s} ; \mathrm{n}=$ $8)$, green ones for $13.2 \mathrm{~s}( \pm 6.2 \mathrm{~s}, \mathrm{n}=5)$. In three further landings, two of them on green pieces, the female held her abdomen straight.

I removed floating leaves from the water surface without disturbing oviposition. Thus the movement of the ovipositor could be examined from close up. However, although deposition of the eggs was not clearly observable, the tip of the valvulae including the styli touched the substrate, the sabre-shaped processor was spread out and placed on the surface. Both leaves of the processor sank into the plant material to their base and the ventral part of the valvulae came in contact with the plant material. During the drawing out movement, the processor was spread out less significantly. Insertion movements followed each $12.7 \mathrm{~s}( \pm 2.4 \mathrm{~s}$ s.d.; $\mathrm{n}=42)$. The insertion rate for series of more than 5 incisions without interruption was 5.5 incisions per minute $( \pm 2.3$ incisions per minute s.d.; $\mathrm{n}=5$ ). Beside deep insertions females also made shallow incisions, not leading to egg deposition. Between insertion movements the female palpated the material for a short time. During these periods, as well as during insertion movements a water meniscus connected the ovipositor and the substrate. When the substrate had no water contact it started to become dry on the surface. When the meniscus disappeared the female stopped palpating and the tandem took off. By moistening the material continuously I suc- ceeded in prolonging the stay and oviposition of a tandem for up to $6.5 \mathrm{~min}$.

\section{Coenagrion caerulescens}

After copulation the males accompanied their mates in tandem. The females settled; males remained in a vertical position on the prothorax of the female without moving. Only during windy conditions did they settle too. Pairs commonly performed oviposition behaviour on dead floating leaves of Scirpus and Juncus. From 46 cases observed $73.9 \%$ lasted up to 20 s $($ minimum $=2 \mathrm{~s}), 15.2 \%$ longer than one minute (maximum $=$ $14 \mathrm{~min} 43 \mathrm{~s}$ ). They formed groups of up to 5 tandems on a 20 $\mathrm{cm}$ long section of a Scirpus leaf. In one case an egg laying female became submerged, only her wings distal of the nodus remained outside of the water, the tandem male grasping a blade submerged to his third abdominal segment.

In the course of the experiments tandems landed on sites with models of conspecifics only (Table 1). They preferred the dead brown leaves significantly (Table 2 ). In 27 landings (=90\%) the female curved her abdomen immediately and touched the substrate for a mean of $11.0 \mathrm{~s} \pm 8.6 \mathrm{~s}$ s.d. (maximum $=44 \mathrm{~s}, \mathrm{n}=$ 20). Three times the female held her abdomen straight (twice at green, once at brown piece). In tandems landing a second time (Table 2) the females always touched the substrate with their ovipositors. Pairs of C. mercuriale which passed the experimental site never landed on the Scirpus leaves. However, they landed on nearby Chara.

\section{DISCUSSION}

Sympecma fusca and Coenagrion caerulescens deposit their eggs in dead plant tissue, but they have different means of oviposition site selection. This may be closely related to their different flight seasons. Before comparing both species the results will be discussed for both species separately.

After overwintering in the adult stage $S$. fusca is the first dragonfly which appears in Central Europe. Reproduction mainly takes place in April, oviposition being well described by Geijskes (1929), Klein (1932), Loibl (1958), Münchberg (1933)

TABLE 1. Choice of oviposition site of Coenagrion caerulescens. Models of conspecifics were alternately fixed to one of two pairs of Scirpus holoschoemus leaves.

\begin{tabular}{lcccccc}
\hline \multirow{2}{*}{ Model } & \multicolumn{2}{c}{ Landing on site } & & \multicolumn{2}{c}{ Difference from 1:1 } \\
\cline { 2 - 3 } \cline { 6 - 7 } & $\begin{array}{c}\text { with } \\
\text { model }\end{array}$ & $\begin{array}{c}\text { without } \\
\text { model }\end{array}$ & & $\chi^{2}$ & $\mathrm{P}$ \\
\hline Ovipositing tandem & 14 & 0 & & 14 & $<0.001$ \\
Vertical male & 13 & 0 & & 13 & $<0.001$ \\
\hline
\end{tabular}

and Robert (1958). As a rule, the female deposits eggs into dead plant material, but, as shown in the experiments, there is no preference. Tandems land on all floating plant pieces and females utilise them if suitable, as suggested by Robert (1958). During the reproductive period of $S$. fusca, from March to May, plant debris formed by waves and ice-floes is floating on the water. S. fusca uses them for oviposition when they are soft. Other plants suitable for oviposition are mainly missing at that time. Water plants have just started to grow and fresh parts are rare on the water surface. Vertical stems and leaves of emergent plants are less suitable. Above the water they are too dry and the eggs probably can not develop. The small section below the water surface which is in reach of the female's ovipositor without submerging may dry out too rapidly, when the water level decreases in springtime. Therefore, wet pieces floating on the water are optimal. 
TABLE 2. Choice of oviposition site of Coenagrion caerulescens. Test between fresh green and dead brown leaves of Scirpus holoschoemus. The first and second, subsequent landing of pairs were recorded, no other dragonflies were present during this time.

\begin{tabular}{lcccccc}
\hline \multirow{2}{*}{$\begin{array}{l}\text { Number of } \\
\text { landings }\end{array}$} & \multicolumn{2}{c}{$\begin{array}{c}\text { Landing and } \\
\text { ovipositor contact on }\end{array}$} & & \multicolumn{2}{c}{ Difference from 1:1 } \\
\cline { 2 - 3 } \cline { 5 - 6 } & brown leaf & green leaf & & $\chi^{2}$ & $\mathrm{P}$ \\
\hline First & 26 & 1 & & 23.1 & $<0.001$ \\
Second & 16 & 1 & & 13.2 & $<0.001$ \\
\hline
\end{tabular}

Robert (1958) reports that $S$. fusca inserts eggs every 2-3 s. This corresponds to an oviposition rate of 20 to 30 eggs per minute. Bick et al. (1976) refer to Robert, but state an egg deposition rate of 120-180 eggs per minute. This erroneous statement is cited by others (e.g. Waage, 1978) and is important, because, if being correct, it would be by far the highest known deposition rate of an odonate depositing eggs endophytically. I cannot confirm this rate. With a mean of 5.5 insertions per minute $S$. fusca oviposits significantly slower than reported by Robert (1958).

The reproductive behaviour and habitat selection of Coenagrion caerulescens has not been thoroughly investigated so far. According to Jurzitza (1988), C. caerulescens deposits into living and dead plant pieces, Schmidt (1959) observed oviposition behaviour on Nasturcium sp. According to the experiments described here, one can suggest that dead wet plant tissue is nearly exclusively used for oviposition. The experiments clearly show that dead soft material is significantly preferred. This is necessary because during the flight season of C. caerulescens an entanglement of dead and fresh plant debris lie in the water. Both materials are comparable in their size and position, but dragonflies may distinguish them by their surface characteristics or colour. The ability or motivation to quickly distinguish between them is particularly required when one of the substrates present is not suitable and searching for a suitable oviposition site costs time and energy. In the case of emergent plants I suggest that Odonata species which have no diapause in the egg stage only successfully oviposit into dead and therefore soaked parts. Fresh tissue has a lower water content than dead plant material in water. Moreover the tough epidermis of the living plant better resists to female's ovipositor.

Additionally, oviposition site selection in C. caerulescens is influenced by the presence of conspecifics and often groups of ovipositing pairs form up, as in other Coenagrion species (Martens, 1989, 1994). The vertical tandem-male is a sufficient stimulus.

The genera Sympecma and Coenagrion have no diapause in the egg stage (Geijskes, 1929, Waringer \& Humpesch, 1984) and they have to deposit their eggs in a wet milieu. For $S$. fusca and $C$. caerulescens, the floating dead parts of emergent macrophytes are the best sites for oviposition. Living emergent plants should be avoided. But, mechanisms of oviposition site selection are quite different in both species. $S$. fusca is not familiar with fresh emergent plants and can not discriminate whereas $C$. caerulescens which finds dead and living plants side by side selects clearly.

ACKNOWLEDGEMENTS. I would like to thank Arne and Adelheid Martens for their reliable assistance in the field, and Reinhard Jödicke and Göran Sahlén for helpful suggestions to the manuscript.

\section{REFERENCES}

BAnKs M.J. \& Thompson D.J. 1985: Lifetime mating success in the damselfly Coenagrion puella. Anim. Behav. 33: 1175-1183.

BANks M.J. \& Thompson D.J. 1987: Lifetime reproductive success of females of the damselfly Coenagrion puella. J. Anim. Ecol. 56: 815-832.

Bick G.H., Bick J.C. \& HornufF L.E. 1976: Behavior of Chromagrion conditum (Hagen) adults (Zygoptera: Coenagrionidae). Odonatologica 5: 129-141.

Geuskes D.C. 1929: Een Juffertje uit Oisterwijk. Sympecma fusca Vanderl., hare leventswijze en ontwikkeling. (= Sympycna fusca Charp.) (= Lestes fuscus Vanderl.). De Levende Natuur 34: 139-143, 179-187.

JÖDICKE R. 1997: Die Binsenjungfern und Winterlibellen Europas (Lestidae). Die Neue Brehm-Bücherei 631. Westarp Wissenschaften, Magdeburg, $277 \mathrm{pp}$.

Jurzitza G. 1988: Welche Libelle ist das? Kosmos Franckh, Stuttgart, $191 \mathrm{pp}$

KLEIN B.M. 1932: Beobachtungen an Odonaten. Biol. Zbl. 52: 709-715.

LorBL E. 1958: Zur Ethologie und Biologie der deutschen Lestiden Odonata). Z. Tierpsychol. 15: 54-81.

Martens A. 1989: Aggregation of tandems in Coenagrion pulchellum (Van der Linden, 1825) during oviposition (Odonata: Coenagrionidae). Zool. Anz. 223: 124-128.

Martens A. 1992: Aggregationen von Platycnemis pennipes (Pallas) während der Eiablage (Odonata: Platycnemididae). Diss. Techn. Univ. Braunschweig, 133 pp.

Martens A. 1993: Influence of conspecifics and plant structures on oviposition site selection in Pyrrhosoma nymphula (Sulzer) (Zygoptera: Coenagrionidae). Odonatologica 22: 487-494.

MARTENS A. 1994: Field experiments on aggregation behaviour and oviposition in Coenagrion puella (L.) (Zygoptera: Coenagrionidae). Adv. Odonatol. 6: 49-58.

MünChBERG P. 1933: Beitraege zur Kenntnis der Biologie der Lestinae Calv. (Odonata). Int. Rev. Ges. Hydrobiol. Hydrogr. 28: 141-171.

Rehreldt G.E., Schridde P. \& Suhling F. 1991: Inventaire et protection des Odonates du Canal de Vergières (B.D.R.). Faune Provence 12: 4-9.

Robert P.-A. 1958: Les Libellules (Odonates). Delachaux \& Niestlé, Neuchâtel, 364 pp.

Schmid E. 1959: Versuch einer Analyse der Libelle Agrion caerulescens Fonsc. 1838. Bull. Inst. R. Sci. Nat. Belg. 35 (29): 1-20.

SCHRDDE P. \& SuHLING F. 1994: Larval dragonfly communities in different habitats of a Mediterranean running water system. Adv. Odonatol. 6: 89-100.

WAAGE J.K. 1978: Oviposition duration and egg deposition rates in Calopteryx maculata (P. de Beauvois) (Zygoptera: Calopterygidae). Odonatologica 7: 77-88.

WAAGE J.K. 1987: Choice and utilization of oviposition sites by female Calopteryx maculata (Odonata: Calopterygidae). 1. Influence of site size and the presence of other females. Behav. Ecol. Sociobiol. 20: 439-446.

WARINGER J.A. \& HuMPESCH U.H. 1984: Embryonic development, larval growth and life cycle of Coenagrion puella (Odonata: Zygoptera) from an Austrian pond. Freshw. Biol. 14: 385-399.

Wendler A. \& Nüss J.-H. 1991: Libellen. DJN, Hamburg, 129 pp.

Received November 30, 1999; revised July 15, 2000; accepted October17, 2000 